\title{
HARMONIZATION OF TAX LEGISLATION OF THE ASEAN COMMUNITY
}

\author{
Tanapong Damkerngkhajornwong \\ Advanced Master of Laws (LL.M), European Tax Law, Leiden University \\ Email: tabalong.da@rd.go.th
}

\begin{abstract}
This article indicates how tax legislations, both in direct and indirect fields, of ASEAN countries should be harmonized. With respect to direct taxation, the issue of direct tax rates harmonization personal income tax and corporate income tax - will firstly be discussed. Further, I will look into how the personal income tax treatment on a resident exercising the free movement of skilled labour should be. In addition, how to enhance the network of tax treaties between ASEAN Member States and withholding tax levied on cross-border transaction will also be described. As regards indirect taxation, I will consider to what extent such the consumption tax systems as VAT and GST in each ASEAN countries could be in accordance with each other. Finally, what challenges over tax harmonization in ASEAN can be will be noted. The majority of the discussions above will be based upon the tax harmonization and coordination already conducted within the EU.
\end{abstract}

Key words: Asean Community; Harmonization; Legislation; Tax.

\section{Introduction}

As precisely known to the global public, the South East Asian countries have integrated into the Association of South East Asian Nations (ASEAN) since 1967. The main aim thereof is to increase economic growth, make social and cultural development as well as to enhance peace and security in South East Asia.At present, memberships are composed of 10 countries namely, in alphabetical order, Brunei, Cambodia, Indonesia, Laos, Malaysia, Myanmar, the Philippines, Singapore, Thailand and Vietnam.

ASEAN was built on three pillars, comprising the ASEAN Political-Security Community (APSC), the ASEAN SocioCultural Community (ASCC) and the
ASEAN Economic Community (AEC). The last pillar (AEC) has been recently regarded as the most important since it aims to implement economic integration initiatives to bring about a single market amongst ASEAN nations. In that respect, the AEC Blueprint (the "Blueprint") was mutually adopted by all the ASEAN Member States with a view to laying down rules and a master plan regarding the attainment of ASEAN common market based on the free movement provisions: free movement of goods, services, investment, skilled labour, and free flow of capital. This has started to come in effect since the end of 2015.As a consequence of integration into single market, an issue arises as to how the harmonization of tax legislation of the 
ASEAN Member States can be made because each Member State constitutes different tax systems.

\section{Analysis and Discussion}

At present, the ASEAN countries prescribed tax rates at a vast variation. To provide clarity, the top bracket for personal income tax rates stays between $20 \%$ in Singapore and $37 \%$ in Thailand whilst a fixed rate of $20 \%$ was adopted by Cambodia and no personal income tax is imposed in Brunei. As to corporate tax rates ,they range from $17 \%$ in Singapore to $30 \%$ in the Philippines whereas Myanmar has a scaled rate of 5\% - 40\% there for. It is apparent that with the entry into ASEAN single market, the variations in tax systems and tax rates are potential to result in competition between ASEAN Member States in order to draw investments and attract skilled labour.The question arises whether it is necessary through direct tax rate harmonization to make sure that tax competition between the countries is minimized.

According to EU circumstance and EU tax law, until recently, there has been no absolute harmonization of both corporate income tax rate and personal income tax rate. On the contrary, the EU has adopted the concept of disparity. Disparity within the ambit of EU tax law arises from the distinctions of legal systems between two or more Member States. As an illustration, in case where a corporation is set up in a Member State imposing the corporate income tax rate of $20 \%$ and it intends to establish a branch in another Member State where the corporate income tax rate is levied at $25 \%$, such corporation may not invoke that the rate in branch State is higher than levied in its home State since the branch State likewise imposes the rate of $25 \%$ on its domestic corporations. ${ }^{1}$

Another case recognizing the disparity is the Gilly ${ }^{2}$ case, whereit concerned Mrs Gilly who has the nationality of Germany and also France as a result of marriage. She lived in France but worked in Germany as a teacher in a state primary school. According to FranceGermany tax treaty, the taxpayer acquiring remunerations from public sector are required to pay tax in the paying state if the taxpayer has the nationality of that state. Consequently, there was double taxation occurring in this case because Mrs Gilly was taxed in Germany under the tax treaty and also taxed as a resident in France. In this respect, the tax treaty therefore eliminated such double taxation by granting a tax credit to French resident for French income tax which can be attributed to the German taxable income. An issue arises however that the tax paid in Germany was more than tax credit to be set off

\footnotetext{
${ }^{1}$ Ben J.M. Terra \& Peter J. Wattel, European Tax Law, Second Edition (The Hague: Kluwer Law International, 2012), at pp. 93-94

${ }^{2}$ ECJ, 12 May 1998, Case C-336/96 Mr and Mrs Robert Gilly v Directeur des services fiscaux du BasRhin, [1998] ECR I-2793
} 
against French tax since Germany adopted a tax scale which is more progressive. Accordingly, French residents working in Germany such as Mrs Gilly can be imposed the higher tax burden than persons acquiring the same income merely in France.

$\mathrm{Mr}$ and Mrs Gilly invoked this case to the ECJ claiming that the heavier tax burden was contrary to the EU free movement of workers since there would have been no such higher burden, if German nationality had not belonged to Mrs Gilly. The ECJ asserted that any unfavourable result incurred in this case was caused by the differences between Member States tax rates upon which the Member States are competent to prescribe in the absence of EU harmonization of direct taxation. In other words, this is the disparity which is compatible with EU law.

As regards the ASEAN circumstance, it appears currently that there is still no provision under ASEAN Charter and secondary law which prescribes the harmonization of direct tax rate. As a consequence, the direct tax rate harmonization amongst ASEAN countries should be that in order to maintain tax sovereignty of each member nations, corporate income tax rate and personal income tax rate shall remain unchanged and the ASEAN should likewise adopt the concept disparity. This is in accordance with the practice laid down in the EU.

As stated above, one of the main goals in creating the ASEAN common market is to bring about the free movement of skilled labour in the ASEAN region.Therefore, the issue which deserves the discussion here is how the tax treatmentson the ASEAN crossborder workers should be because when a resident in one Member State exercises his free movement right, moving to work in another Member State, he will be subject also to taxation in the Member State of work.

Within the circumstance of the EU, the ECJ has held in a number of cases entailing the different treatment on personal income tax. First of all, with regard to the matters of personal income tax rates, the ECJ has held in the Asscher ${ }^{3}$ case that a Member State shall apply to income of a self-employed nonresident taxpayer the same tax rate as it applies to its resident taxpayers who carry on the same activity. It is contrary to the freedom of establishment if such Member State applies the rates, which are more favourable to its residents. The ECJ further noted that both residents and non-residents of the Member State of work are in comparable situations since the residence state of the non-resident applies under a tax treaty the exemption with progression. In short, the Member State of work must apply the same personal income tax rate to both resident worker and nonresident worker if they are in comparable situations.As regards the income-related

\footnotetext{
${ }^{3}$ ECJ, 27 June 1996, Case C-107/94 P. H. Asscher v Staatssecretaris van Financiën, [1996] ECR I-03089.
} 
deductions, in the Conijn ${ }^{4}$ case, the ECJ observed that a non-resident taxpayer in the Member State of work shall acquire the right of deductions of expenses, which are relevant directly to an income generating activity there, in the same way as it provides to a resident taxpayer.

In pursuance of the ASEAN free movement of skilled labour, it is essential for the ASEAN to adopt the secondary laws.Such laws, as compliant with the respective ECJ case law rendered above, shall provide that the ASEAN Member States of work must treat the non- resident taxpayers who moved to work there the same way as it treats its resident taxpayers on the condition that they are in the comparable situations. The mentioned treatments include, but not limited to, the tax rate, tax credit and the right of expenditure deductions. With respect to the tax rates, the equal tax rate shall be applied to both resident and non-resident taxpayers. As for the right of expenses deduction, in case where the Member States of work give such rights to its resident taxpayer, they must also provide them to the non-residents taxpayers.For the avoidance of doubt in applying these laws, the definition of the comparable situations shall likewise be provided for therein.

According to item 29 vii.of the Blueprint, it intends to promote ASEAN as an integrated investment area and production

\footnotetext{
${ }^{4}$ ECJ, 6 July 2006, Case C-346/04 Robert Hans Conijn v Finanzamt Hamburg-Nord, [2006] ECR I-06137.
}

network. In that regard, it lays down an actionto set up an effective network of bilateral agreements on avoidance of double taxation among ASEAN countries. In addition, point $58 \mathrm{i}$. thereof stipulates the creation of ASEAN tax treaties network to be completed by the end of 2010. Nevertheless, until now such the network has not been fully completed yet because all of the ASEAN countries remain unable to have tax treaties with each other.

The similar issues take place also in the EU's current situation where not all of the Member States has entered into the tax treaties with each other. Hence, the EU has solved this problem by way of adopting a number of secondary laws (Directives) with a view to facilitating the avoidance of double taxation between EU Member States. Notwithstanding the advent of such Directives, not all of the double taxation is yet eliminated since those Directives deal with merely certain categories of income. In other words, until recently there have been only Directives entailing the income derived from dividend, interest, royalty and merger and acquisition between Member States.

The EU has adopted the ParentSubsidiary Directive (PSD) so as to deal with income derived from EU cross-border dividend. As a general fact, there are two tax issues occurring in the situation where a subsidiary in a Member State pays its dividend to its parent company in another Member 
State. Firstly, the Member State of subsidiary usually imposes a withholding tax on outbound dividends. Secondly, the Member State of parent company may also make inclusive the received dividend in the parent company's taxable income. These two problems give rise to economic double taxation where the same income is taxed twice on both the subsidiary and the parent company. ${ }^{5}$ The PSD aims to discard these tax obstacles incurred on cross-border dividend payment within the group companies. This is in order to render more effective the exercise of free movement of capital and establishment.

The main principle of the PSD provides that the dividends paid by the EU subsidiary to EU parent company shall be exempt in the Member State of subsidiary. Furthermore, the Member State of parent company shall also not tax the dividend income received by the parent company or may tax with granting a tax credit against parent company's tax for tax paid in the Member State of subsidiary.

With respect to the ASEAN circumstance, as stated above, until now the network of tax treaties amongst ASEAN countries has not been fully completed yet, which gives rise to the double taxation between them. Accordingly, with a view to abolishing double taxation for the dividend income, ASEAN should likewise adopt such

\footnotetext{
${ }^{5}$ Hamaekers, Hubert, Taxation Trends in Europe, AsiaPacific Tax Bulletin (2003), pp.42-50.
}

the secondary law as the PSD to prevent the Member States from suffering the double taxation within ASEAN community. The adoption of the PSD in ASEAN will also reflect the free flow of investment in item 23 of the Blueprint, which aims to create free and open investment regime and to enhance ASEAN's competitiveness in attracting foreign direct investment (FDI) as well as intra- ASEAN investment. It is expected that the dynamic development of ASEAN economies will be brought about by the new investments and reinvestments arising therefrom.

In order to prescribe the ASEAN PSD, the EU PSD is able to be a proper model. Therefore, in the ASEAN PSD, which will as well constitute the main purpose of eliminating double taxation on cross-border dividends and of creating tax treaties network, the majority of the provisions will be identical to the EU PSD. As a clarification, the gist of the ASEAN PSD will be that the ASEAN countries of parent company shall not impose any tax on the dividend income received by the parent company from the subsidiary. Nonetheless, they may remain to levy tax thereon but are required to provide tax credit. In respect of the countries of subsidiary, they must not levy withholding tax on the dividend distribution by the subsidiary.

Identical to the dividend income, the EU has likewise adopted the Interest and Royalty Directive (IRD) in order to eliminate double 
taxation arising therefrom. It appears that the withholding taxes on cross-border payments of interest and royalty are giving rise to the issues less detrimental than those occurring from dividend withholding tax. The rationale behind this is that the payments of interest and royalty can be deducted from the debtor company's taxable profits, which is in contrast to the dividend income. Moreover, most of the tax treaties in general provide for the reduction or the exemption on withholding tax. Also, the majority of Member States do not impose a withholding tax upon the interest and royalty paid therefrom. Nevertheless, despite the reasons stated above, the existence of double taxation sometimes is there because not all Member States has the bilateral tax treaties with each other, and the reduction of withholding tax can be time-consuming. The gist of the IRD is the requirement that the Member States of paying company must refrain from taxing the payment of interest and royalty. The prohibited taxing includes both the withholding tax and the assessment.

Not all of the ASEAN countries has the bilateral tax treaties with each other, thus making the companies established there suffer the double taxation upon some types of incomes, including the interest and royalty. Besides, in spite of the fact that some ASEAN countries have already entered into tax treaties with most of other ASEAN countries, the double taxation on interest and royalty between them may exist because most of the tax treatiesprovide merely the reduction of withholding tax. As an illustration, Thailand currently has tax treaties with all of ten ASEAN countries, except Brunei as well as Cambodia, which is at present in the stage of negotiation. However, some of those tax treaties do not render the full exemption on the interest and royalty income, hence giving rise tothe double taxation tolerated by the companies established in Thailand and the other ASEAN country. In this respect, it is considered essentialfor the ASEAN to adopt the ASEAN IRD, the main purpose of which is to facilitate the creation of tax treaties network between ASEAN countries, particularly on the abolishment of double taxation. The ASEAN IRD could be adopted through applying the EU IRD structure as a model, which constitutes the identical aim of eliminating the double taxation. Consequently, like the IRD, the major aimof the ASEAN IRD will be the abolishment of double taxation arising from ASEAN cross-border interest and royalty payment.

Most importantly, the issuance of the ASEAN IRD will also be in accordance with Item 31 of the Blueprint, which aims to enhance withholding tax structure in order to promote the broadening of investor base in ASEAN debt issuances. The withholding tax exemption granted by the AIRL, particularly on the interest, is expected to contribute to the larger number of investors wishing to take a loan in investing across the ASEAN. 
Likewise, the absence of withholding tax on interest and royalty payment will lead to the genuine internal market.

In the ASEAN, currently there has already been the process of tariff harmonization since all of the Member States have entered into the Agreement on the Common Effective Preferential Tariff (CEPT) Scheme for the ASEAN Free Trade Area (AFTA). Unlike the EU, a common external tariff on imported goods is not applied by the CEPT. In this respect, each of ASEAN countries is entitled to apply its own national laws in imposing tariffs upon goods coming from outside ASEAN. On the other hand, as regards goods originating within ASEAN, a tariff rate of $0-5 \%$ shall be applied by ASEAN countries. The reduction of tariff rates has been processed step by step in accordance with the schedule provided for in the CEPT.

However, with regard to such the consumption taxes as Value Added Tax (VAT) and Goods and Services Tax (GST), the harmonization remains needed. More complicatedly, the consumption tax rates applied by most ASEAN countries are various because the rate ranges from $7 \%-12 \%$ whilst Brunei and Myanmar have not yet prescribed GST or VAT and Malaysia has recently made effective the GST with rate of $6 \%$ since 1 st April 2015. ${ }^{6}$ Consequently, it is essential to look at how the EU has harmonized its consumption tax system so that the ASEAN

\footnotetext{
${ }^{6}$ See Esther Koisin, supra note 2, same page.
}

could adopt it as a model.

The EU has harmonized its VAT system by way of prescribing the VAT Directive (2006/112/EC), thus making all of the EU Member States apply the same VAT system. Such system involves the offset mechanism, where there are input and output VAT concerned. The VAT Directive was,in other words, adopted as guideline rules for all the Member States to implement VAT systems in their own sovereignty. ${ }^{7}$ It also requires each Member State to transpose the Directive into its national law, which means that all the Member States must impose VAT in the same characteristic notwithstanding the dissimilarity in their legal systems. As a consequence of such transposing, the transposed national laws must be interpreted as in compatibility with the VAT Directive, and any vagueness in such interpretation can be submitted to the ECJ to provide a clarification. The main structure of the VAT Directive constitutes the features as follows: ${ }^{8}$

1. Who is the taxable person? - This feature is stated in Art. 9-13 of the Directive. Art. 9 thereof provides that a taxable person is any person who carries out in any place any economic activity, whatever the purpose or results of that activity.

\footnotetext{
${ }^{7}$ Ad van Doesum and Frank Nellen, VAT in a Day: A Concise Overview of the EU VAT System, Kluwer a Wolters Kluwer business (2012), pp.9-11.

${ }^{8}$ Ibid.
} 
The term "economic activity' is defined by the Directive as any activity of producers, traders or persons supplying services, including the exploitation of tangible or intangible property for the purpose of obtaining income on a continuing basis.

2. What is the taxable transaction? As stipulated in Art. 2(1) of the Directive, there are four taxable events, namely, the supply of goods, the supply of services, the intraCommunity acquisition of goods and the importation of goods.As for the supply of goods and services, these transactions must meet the four conditions in order to be considered as taxable. The conditions are that there must be (i) a supply of a good or a service, (ii) for consideration, (iii) within the territory of a Member State (iv) by a taxable person acting as such. As regards the importation of goods, because goods from outside the EU are perhaps not levied the VAT, it is essential to regard it as a taxable transaction for VAT in order to eliminate the distortion of competition.

3. Where is the VAT charged? - Since the VAT is the tax levied on consumption, the place where the
VAT can be charged shall be the place of supply. In order to ascertain where the place of supply is, it is first of all to determine which type of the taxable transactions is because the respective rules provide for the different consequence. By way of an illustration, Art. 32 the VAT Directive stipulates that the place of supply of goods is where the transport of goods begins. However, in case wherethere is no dispatch or transportation of goods, the place of supply shall be the place where the goods are located at the time when the supply takes place. As regards the supply of services, the place of supply depends upon the types of service recipients. If the recipient is the taxable person, the place of supply, in accordance with Art. 44, shall be where the business of recipient is established or where he regularly resides or has fixed address. The rationale behind this is that the right to charge VAT is ensured to occur in the place where the consumptions happen. On the contrary, if the service recipient is the non-taxable person, the place of supply, as pursuant to Art. 45, shall be where the supplier has his business established.

4. What are the taxable amount and tax 
rate?- According to Art. 73 of the VAT Directive, it provides that the taxable amount for supply of goods and services shall be everything which constitutes considerationobtained or to be obtained by the supplier in return for the supplyfrom the customer or a third party, including subsidies directly linked to the price of the supply. In respect of the tax rate, Art. 96 and 97 require the Member States to adopt a standard VAT rate at least $15 \%$ of the taxable amount.

5. Exemptions - The exemption provision requires the taxable person who carries on the supply not to levy the output VAT upon its customers. Thus, such the taxable person has no right to deduct the input tax he paid for goods and services provided in relation to his exempt output transaction. Precisely, it can be said that the VAT exemption can work most effectively merely in case where the taxable person has little or no input VAT because the non-deductibility of the input tax can cause the supplier to suffer more VAT than he should.

Brunei and Myanmar have not prescribed the consumption tax in their country yet. Hence, in order to create the internal market with fair competition amongst the ASEAN countries, the secondary law on ASEAN VAT should be adopted. Definitely, it is suitable to apply the EU VAT Directive as a model in creating the structure of the ASEAN VAT law since the EU VAT has been in force for a great period and is currently working effectively.

The ASEAN VAT system, like the EU VAT, should be the offset mechanism. Also, the structure thereof will constitute the same features, namely, taxable person, taxable transaction, the moment of charging VAT, the taxable amount and tax rate as well as the exemptions. As regards the VAT rate, it must be considered carefully to adopt the common rate, because the VAT rate will affect the price of goods and services whilst the cost of living in each ASEAN countries remains various.

Unlike the EU, until now the ASEAN has not yet established any institution competent to supervise the Member States in conforming to the ASEAN laws. As a consequence, when the ASEAN secondary laws entailing tax harmonization are in force, it is difficult to ensure whether all the Member States transpose those laws into their national legislations or whether they transpose them correctly. Further, if there is the vagueness in applying the national laws relating to the transposing, the problems may arise as to how the solutions should be since currently in the ASEAN there is no 
institution like the ECJ to provide a clarification.All in all, it is possible in future that the ASEAN will have the institution given the full authority to control over the ASEAN countries' compliance with the ASEAN laws, which is expected to result in more effective application thereof.

\section{Conclusion}

In summary, the harmonization of ASEAN tax legislations is at present not yet fully conducted. With a view to doing so, the tax harmonization of EU countries could be a proper model. In the ambit of direct taxation, as regards rates of personal and corporate income tax, the EU adopted the concept of disparity under which tax rates of each Member States remain unchanged. In respect of treatment on personal income tax when a resident of a Member State moves to work in another Member State, it was laid down that any discrimination on tax rates thereof must be eliminated. The network of tax treaties within EU circumstance is somewhat developed. There are such the secondary laws as PSD and IRD, which have been created to eliminate double taxation incurred on dividend and interest incomes. However, the harmonization of indirect taxation is more solid than the direct one. The EU has prescribed VAT Directive aiming to unify the system of EU consumption tax. The VAT Directive provides for the structures and details of VAT legislation in which all the
Member States are required to transpose into their national laws in the identical characteristics.

\section{Reference}

Ad van Doesum and Frank Nellen, (2012). VAT in a Day: A Concise Overview of the EU VAT System, Kluwer a Wolters, Kluwer business.

Ben J.M. Terra \& Peter J. Wattel, (2012) European Tax Law, Second Edition (The Hague: Kluwer Law International.

Esther Koisin, (2014) The Conference on Variations in National Tax Systems and its Effect on Regional Tax Integration of Different Tax Systems: "The EU Experiences and its Lessons for ASEAN",(Malaysia: The Inland Revenue Board of Malaysia (IRBM)2014)

ECJ, 27 June 1996, Case C-107/94 P. H. Asscher v Staatssecretaris van Financiën, [1996] ECR I-03089.

ECJ, 12 May 1998, Case C-336/96 Mr and Mrs Robert Gilly v Directeur des services fiscaux du Bas-Rhin, [1998]

ECR I-2793.

ECJ, 12 July 2005, Case C-403/03 Egon Schempp v Finanzamt München, [2005] ECR I- 6421.

ECJ, 6 July 2006, Case C-346/04 Robert Hans Conijn v Finanzamt HamburgNord, [2006] ECR I-06137.

Hamaekers, Hubert, Taxation Trends in Europe, Asia-Pacific Tax Bulletin (2003). 